\title{
Publisher Correction: Recycled iron fuels new production in the eastern equatorial Pacific Ocean
}

\author{
Patrick A. Rafter (D) ${ }^{1}$, Daniel M. Sigman ${ }^{2} \&$ Katherine R.M. Mackey ${ }^{1}$
}

Nature Communications 8:1100 10.1038/s41467-017-01219-7; Article published online: 24 October 2017

The original version of this Article contained errors in Fig. $2 b$ and Table 2. In Fig. $2 b$, the white circle labels were incorrectly positioned as they referred to scenarios that were used in an earlier version of the Article. In Table 2, the following three sentences were removed from the legend "The last two calculations are discussed in the "Methods". The first assumes that all dissolved plus the $\approx 0.3 \mathrm{nmol} \mathrm{kg}{ }^{-1}$ of particulate iron (measured in the eastern equatorial Pacific ${ }^{30}$ ) is bioavailable. The last calculation assumes EUC dissolved iron concentrations from $140^{\circ} \mathrm{W}^{\prime}$. These errors have now been corrected in both the PDF and HTML versions of the Article.

Published online: 05 December 2017

\begin{abstract}
(c) (i) Open Access This article is licensed under a Creative Commons Attribution 4.0 International License, which permits use, sharing, adaptation, distribution and reproduction in any medium or format, as long as you give appropriate credit to the original author(s) and the source, provide a link to the Creative Commons license, and indicate if changes were made. The images or other third party material in this article are included in the article's Creative Commons license, unless indicated otherwise in a credit line to the material. If material is not included in the article's Creative Commons license and your intended use is not permitted by statutory regulation or exceeds the permitted use, you will need to obtain permission directly from the copyright holder. To view a copy of this license, visit http://creativecommons.org/licenses/by/4.0/.
\end{abstract}

(C) The Author(s) 2017

\footnotetext{
${ }^{1}$ Department of Earth System Science, University of California, Irvine, CA 92697, USA. ${ }^{2}$ Department of Geosciences, Princeton University, Princeton, NJ 08540, USA. Correspondence and requests for materials should be addressed to P.A.R. (email: prafter@uci.edu)
} 